\title{
Minor psychiatric disorders among nurses university faculties
}

\author{
Juliana Petri Tavares ${ }^{1}$ \\ Carmem Lúcia Colomé Beck² \\ Tânia Solange Bosi de Souza Magnago ${ }^{3}$ \\ Roselaine Ruviaro Zanini ${ }^{4}$ \\ Liana Lautert ${ }^{5}$
}

This cross-sectional study addresses 130 nursing faculty members in federal universities from Rio Grande do Sul, Brazil. It investigated the psychological demands and decision latitude (the Demand-Control Model by Karasek) and their association with Minor Psychological Disorders (MPDs). The Brazilian versions of the Self-Report-Questionnaire-20 and the Job Stress Scale were used. MPDs were prevalent in $20 \%$ of the studied individuals. After adjusting for potential confounders, the chances of participants presenting mental disorders were higher in the quadrant 'active strain jobs' (OR=14.23, 95\% CI 1.55 to 130.73$)$, followed by the 'high strain jobs' quadrant (OR=10.05, 95\% CI 1.23 to 82.44), compared to nursing professors classified in the 'low strain jobs' quadrant. We conclude that high psychological demands and low control over work can cause disorders in nursing professors, among them, MPDs.

Descriptors: Nursing; Occupational Health; Mental Disorders; Faculty, Nursing; Work.

\footnotetext{
${ }^{1}$ RN, Doctoral Student in Nursing, Universidade Federal do Rio Grande do Sul, Porto Alegre, RS, Brazil. Scholarship holder Coordenação de Aperfeiçoamento de Pessoal de Nível Superior (CAPES). E-mail: jupetritavares@gmail.com.

2 RN, Ph.D. in Nursing, Associate Professor II, Departamento de Enfermagem, Universidade Federal de Santa Maria, RS, Brazil. E-mail: carmembeck@gmail.com.

${ }^{3}$ RN, Ph.D. in Nursing, Adjunct Professor, Departamento de Enfermagem, Universidade Federal de Santa Maria, RS, Brazil. E-mail: tmagnago@terra.com.br.

${ }^{4}$ Mathematician, Ph.D. in Epidemiology, Adjunct Professor, Departamento de Estatística, Universidade Federal de Santa Maria, RS, Brazil. E-mail: rrzanini@terra.com.br

${ }^{5}$ RN, Ph.D. in Psychology, Associate Professor, Universidade Federal do Rio Grande do Sul, Porto Alegre, RS, Brazil. E-mail: lila@enf.ufrgs.br.
}

Corresponding Author:

Carmem Lúcia Colomé Beck

Universidade Federal de Santa Maria. Departamento de Enfermagem

Rua Roraima, 1000, Cidade Universitária

Bairro: Camobi

CEP: 97105-900, Santa Maria, RS, Brasil

E-mail: carmembeck@gmail.com 


\section{Distúrbios psíquicos menores em enfermeiros docentes de universidades}

Trata-se de estudo epidemiológico seccional, incluindo 130 enfermeiros docentes das Universidades Federais do Rio Grande do Sul, Brasil, que teve por objetivo investigar a demanda psicológica e o controle sobre o trabalho (Modelo Demanda-Controle de Karasek) e sua associação com os distúrbios psíquicos menores. Foram utilizadas as versões brasileiras do Self-Report-Questionnaire-20 e da Job Stress Scale. A prevalência de distúrbios psíquicos menores foi de $20,1 \%$. Após ajustes, a fim de se evitar potenciais confundidores, a chance de distúrbios psíquicos foi maior no quadrante trabalho ativo $(O R=14,23$; IC95\%=1,55-130,73), seguido do quadrante alta exigência $(O R=10,05$; IC95\% $=1,23-82,44)$, quando comparado aos enfermeiros docentes do quadrante baixa exigência. Conclui-se que a alta demanda psicológica e o baixo controle sobre o trabalho podem desencadear acometimentos, dentre eles os distúrbios psíquicos menores em enfermeiros docentes.

Descritores: Enfermagem; Saúde do Trabalhador; Transtornos Mentais; Docentes de Enfermagem; Trabalho.

\section{Disturbios psíquicos menores en enfermeros docentes universitarios}

Estudio epidemiológico seccional entre 130 enfermeros docentes de las universidades federales del estado de Rio Grande do Sul, en Brasil, que tuvo como objetivo investigar la demanda psicológica y el control del trabajo (Modelo Demanda-Control de Karasek) y sus asociaciones con Disturbios Psíquicos Menores. Se utilizaron las versiones brasileñas del Self-Report-Questionnaire-20 y del Job Stress Scale. La prevalencia de Disturbios Psíquicos Menores fue del 20,1\%. Después de ajustar los posibles factores de confusión, las posibilidades de trastornos psíquicos fueron mayores en el cuadrante Trabajo Activo $(\mathrm{OR}=14,13$; IC95\%=1,55-130,73), seguido del cuadrante Alta exigencia (OR=10,05; IC95\%=1,23-82,44), en comparación con los enfermeros docentes del cuadrante Baja Exigencia. Se concluyó que la alta demanda psicológica y el bajo control del trabajo pueden provocar daños a la salud, entre ellos los Disturbios Psíquicos Menores en enfermeros docentes.

Descriptores: Enfermería; Salud Laboral; Trastornos Mentales; Docentes de Enfermería; Trabajo.

\section{Introduction}

In addition to teaching, the work of nursing professors involves research, assisting students, and interpersonal relationships with their colleagues and other professionals, students, superiors and other elements existing in the work place $^{(1)}$. The teaching profession has been identified as the profession most exposed to conflictive environments with highly demanding work tasks, including extra-class tasks, meetings, problems with students, schedules, and routines that may expose workers to stressful situations(2).

Job strain may result from a mismatch between demands from the professional practice and the worker's ability to cope with such demands, once demands are established in the locus of work and workers experience different degrees of control over the tasks they perform $^{(3-4)}$.

Among the models that investigate occupational stress, the Demand-Control Model (DC Model) or Job Strain, proposed in the late $1970 s^{(3)}$ by Robert Karasek, stands out. This model investigates two psychosocial dimensions in the workplace, 'psychological demands' and 'decision latitude', and the risk of workers becoming sick$^{(3,5)}$. 'Psychological demands' refer to pressure such as the time/speed demanded in the performance of tasks and conflicts among contradictory demands. 'Decision latitude' is related to the possibility of workers using their intellectual skills to perform their work and have sufficient decision-making authority on how and when to perform tasks ${ }^{(3,5)}$. 
The DC Model assesses the psychosocial environment of the workplace through the combination of high and low levels of the two dimensions, which are divided into four specific kinds of jobs that suggest different risks are posed to health. They are: high strain jobs (a combination of high psychological demand and low decision latitude - greatest risk to health); active strain jobs (high demand and high decision latitude); low strain jobs (low demand and high decision latitude - lowest risk) and passive jobs (low demand and low decision latitude)(3). The DC Model has been used in recent decades in various countries to assess the association between high strain jobs and some outcomes, such as cardiovascular disorders(5), musculoskeletal disorders(6), minor psychiatric disorders $^{(7)}$, diseases of the digestive system ${ }^{(3)}$, and absenteeism ${ }^{(8)}$, among others.

Among the mentioned disorders, Minor Psychiatric Disorders (MPDs) occur in the presence of significant organic disorders arising from the individual's response to a stimulus considered to be a stressor ${ }^{(9)}$. According to estimates of the World Health Organization (WHO), MPDs affect about $30 \%$ of workers and severe mental disorders affect from $5 \%$ to $10 \%$ of workers $^{(10)}$. MPDs refer to clinical conditions of individuals with symptoms such as anxiety, sadness, fatigue, diminished concentration, irritability, insomnia, depression or somatization and which do not satisfy all the criteria defining mental disease according to the International Classification of Diseases (ICD-10) ${ }^{(11-12)}$.

The workplace in the health field imposes physical and mental demands on workers. Consequently, MPDs are increasingly more prevalent among professionals within this field, especially nursing workers $^{(4,13)}$. Some studies $^{(2,14)}$ report that professionals in the field of education have been also affected by these disorders, such as teachers in the municipal teaching system.

Therefore, evaluating the stressors present in the workplace of nurses teaching in federal educational institutions is relevant, as well as the repercussions of job strain on these workers' mental health.

Nursing professors utilize the teaching/learning process in all their care actions, including not only actions directed to the patient and family but also those directed to students, nursing staff and those related to technical procedures ${ }^{(15)}$

This study investigates the dimensions of 'psychological demand' and 'decision latitude' and their association with MPDs experienced by nurses teaching in Federal Universities in Rio Grande do Sul, Brazil.

\section{Method}

Study design and setting: cross-sectional epidemiological study conducted with nurses teaching in the nursing programs of six federal universities in Rio Grande do Sul, Brazil. One of the universities has two nursing programs (in the headquarters and in another campus of the university).

Study population: 177 nursing faculty members, of which all those under temporary contracts (substitute professors), on any kind of leave (including those who left for professional training), and teaching undergraduate programs other than nursing, were excluded, leaving a total of 144 eligible nursing teachers. A total of 130 $(90 \%)$ individuals answered the questionnaire, resulting in a $10 \%$ of loss due to refusals to participate in the study.

Data collection (procedure and instrument): data were collected at two different points in time (from December 2009 to January 2010 and from May to July 2010). Both periods, however, did share a similar characteristic, that is, the end of school semester. Those collecting data at the studied universities were also included to avoid loss of data.

A self-applied questionnaire composed of five distinct modules was used to collect data: Module $A$ included two questions related to the identification of the study date and setting; Module B included eight questions related to the participants' socio-demographic profile; Module $\mathrm{C}$ included ten questions addressing the participants' occupational profile; Module D consisted of 17 questions from the short version of the Job Stress Scale (JSS) ${ }^{(5)}$; while Module E included 20 questions from the Self-Report Questionnaire 20 (SRQ-20)(16).

Data organization and analysis: the Epi-info ${ }^{\circledR}$ program, version 6.4, was used to store data through double data entry. After checking for errors and inconsistencies (validated), data were analyzed through the PASW Statistics ${ }^{\circledR}$ (Predictive Analytics Software, da SPSS Inc., Chicago - USA), version 18.0 for Windows.

The JSS ${ }^{(5)}$, considered to be an independent variable, includes 17 questions: five refer to psychological demand, six to decision latitude, six to social support. The dimensions 'psychological demand' and 'decision latitude' were measured on a scale from 1 to 4 : always (4), sometimes (3), rarely (2) and never (1). The two dimensions present a reverse question each, in which the following scale applies: always (1); sometimes (2) rarely (3) and never (4).

An average value was used as a cut-off point to dichotomize the variables 'psychological demand' and 
'decision latitude'. The levels of demand and control were dichotomized into high and low and the following groups were created to compose the DC Model's quadrants: Iow strain jobs, active strain jobs, passive strain jobs, and high strain jobs.

MPDs, considered to be dependent variables, were assessed according to the scores obtained in the SRQ-20, which was validated in Brazil at the end of the $1980 s^{(16)}$. The cut-off point indicating an MPD was seven positive answers, for both women and men, based on previous studies conducted with nursing workers and teaching professionals ${ }^{(2,13-14)}$.

The following co-variables were considered: a) socio-demographic information: age (26 to 47 years old and from 48 to 68 years old); gender (male and female); schooling (specialization/master's and doctoral degrees/post doctorate); self-reported race according to the IBGE classification*; marital status (married and single/widowed); number of children (none, one to two children and more than three children); per capita family income (up to six times the minimum wage and more than seven times the minimum wage); b) occupational information (assistant professor, professor adjunto ${ }^{+}$, full/associate professor); work regime (40 hours and 40 hours with exclusive dedication, that is, the exercise of another paid activity, whether public or private, is prohibited); time working at the institution (less than a year, from one to ten years, from 11 to 20 years, and more than 20 years); teaching activities (undergraduate and undergraduate/graduate programs); extension activities (yes and no); number of advisees in the last semester (undergraduate, graduate and undergraduate research); social support (high and low).

Bivariate analysis was performed after descriptive analysis of the socio-demographic and occupational characteristics of the participants were conducted. Chi-square test or Fisher's exact test was performed to check whether the associations found were statistically significant at a confidence level of $95 \%$. Multivariate regressions (Enter method) were used to identify associations adjusted for confounding factors among the DC Model's quadrants and MPS. In these analyses, co-variables were considered confounding variables if associated both with the outcome (MPD) and the exposure (DC Model's quadrants) at a confidence level of $95 \%(p \leq 0.25)$, using the Chisquare and Odds Ration (OR). The quadrant 'low strain jobs' was considered to be a reference group, as recommended by the $\mathrm{DC} \mathrm{Model}^{(3)}$, both in the bivariate and multivariate analyses.

Ethical aspects were met in accordance with Resolution 196/96. Those who agreed to participate in the study signed free and informed consent forms. The study project was approved by an Ethic Research Committee according to the Certificate of Ethical Appreciation No. 0264.0.243.000-09 on November 17th 2009 (process No. 23081.014364/2009-66).

\section{Results}

The participants were mainly women (90.8\%, $\mathrm{N}=118$ ) with an average age of 47 years old $( \pm 4.65)$, minimum of 26 and maximum of 68 years old. In relation to schooling, $56.9 \%(\mathrm{~N}=74)$ had a doctoral degree; $93.1 \%(\mathrm{~N}=121)$ reported themselves to be White; $74.6 \%(\mathrm{~N}=97)$ were married; $50 \%(\mathrm{~N}=65)$ had one or two children; $50.5 \%(\mathrm{~N}=56)$ had a family per capita income up to six times the minimum wage; and $73.8 \%(\mathrm{~N}=96)$ had up to three dependents.

Half $(\mathrm{N}=65)$ of the participants were at the adjunto level; 93.1\% ( $\mathrm{N}=121)$ worked 40 hours/week with exclusive dedication; $30 \%(\mathrm{~N}=39)$ worked for more than 20 years at the institution; $50.8 \% \quad(N=66)$ developed teaching activities in the undergraduate program and $49.2 \% \quad(\mathrm{~N}=64)$ in the undergraduate and graduate programs, concomitantly. In relation to research and extension activities, 91.5\% ( $\mathrm{N}=119)$ and $85.4 \%(N=111)$ reported such activities, respectively. In the last semester, a total of $76.2 \%$ of the participants advised up to five undergraduate students; $56.2 \%$ did not advise undergraduate research students, and 50\% advised graduated students.

Almost all the interviewees (98.5\%, N=128) reported no other jobs. The second job reported by two $(1.5 \%)$ participants was also in the teaching field and the extra workload for one of them was two hours/week and four hours/week for the other participant.

The JSS's general consistency (Cronbach's alpha) was 0.54 . The nursing faculty members were most frequently classified in the quadrant 'high strain jobs' (37.7\%, N=49), followed by 'passive strain jobs' (26.2\%, $\mathrm{N}=34)$, 'low strain jobs' $(21.5 \%, \mathrm{~N}=28)$, and 'active strain jobs' (14.6\%, $\mathrm{N}=19)$.

\footnotetext{
* T.N. The Brazilian Institute of Geography and Statistics (IBGE) uses a color classification: White, Black, Pardo (Mixed origin), Yellow (East Asian) and Indígena (Ameridian).

${ }^{\dagger}$ T.N. Brazilian Federal Universities have four hierarchical levels in academic career. Professor Adjunto refers to the second level.
} 
The analysis between the DC Model quadrants' socio-demographic co-variables revealed statistical significance for schooling and race $(p<0.05)$. Those with a doctoral degree or postgraduate experience were more frequently classified in the quadrant 'high strain jobs' (47.4\%, N=37), except those with a specialization or a master's degree, who were classified in the 'passive strain jobs' $(42.3 \%, N=22)$. The participants reporting to be Black or of mixed race were most frequently classified in the quadrant 'active strain jobs' (44.4\%, N=4), while White individuals were classified in the quadrant 'high strain jobs' (38\%, N=46).

The analysis between the model's quadrants and occupational co-variables revealed that professores adjunto (50.8\%, $\mathrm{N}=33)$, those working from 11 to 20 years at the institution $(58.6 \%, N=17)$, those concomitantly teaching in the undergraduate and graduate programs $(45.3 \%, \mathrm{~N}=29)$, and those advising from six to 12 undergraduate research students (45.5\%, $\mathrm{N}=5$ ) were predominantly classified in the quadrant 'high strain jobs', with statistically significant differences among the studied groups $(p<0.05)$.

The SRQ-20's Cronbach's alpha was 0.82. The overall prevalence of suspected MPDs among the participants was $20.1 \%$. No statistically significant difference ( $p>0.05)$ was found when the socio-demographic covariables and the percentage of MPDs were analyzed. With regard to occupational co-variables, those who did not perform extension activities and those performing research presented a greater percentage (36.8\% and $21.8 \%$ respectively) of MPDs, with statistically significant differences among the studied groups $(p<0.05)$.

When the percentage of MPDs was evaluated according to the model's quadrants, we observed that the prevalence of MDPs was the highest in the 'active strain jobs' $(36.8 \%)$, followed by the quadrants 'high strain jobs' (30.6\%), 'passive strain jobs' $(8.8 \%)$, and 'low strain jobs' (3.6\%). The differences found were statistically significant $(p<0.05)$, which confirms that the groups are independent.

Then main results obtained in the analyses of raw and adjusted associations among the DC Model's quadrants and MPDs are described in Table 1.
Table 1 - Raw and adjusted associations among the DC Model's quadrants and minor psychological disorders in nursing faculty members of Federal Universities in Rio Grande do Sul, Brazil, 2010

\begin{tabular}{|c|c|c|c|c|}
\hline \multirow[t]{2}{*}{ DC Model } & \multicolumn{2}{|c|}{$\begin{array}{c}\text { Raw Association* } \\
\text { MPD }\end{array}$} & \multicolumn{2}{|c|}{$\begin{array}{c}\text { Adjusted } \\
\text { Association } \\
\text { MPD }\end{array}$} \\
\hline & OR & $\mathrm{Cl}$ & OR & $\mathrm{Cl}$ \\
\hline Low strain jobs & 1.00 & - & 1.00 & - \\
\hline Passive strain jobs & 2.61 & $0.26-26.62$ & 2.72 & $0.26-28.53$ \\
\hline Active strain jobs & 15.75 & $1.74-142.55$ & 14.23 & $1.55-130.73$ \\
\hline High strain jobs & 11.91 & $1.47-95.95$ & 10.05 & $1.23-82.44$ \\
\hline
\end{tabular}

Non-adjusted analysis showed that nursing faculty members classified in the quadrant 'active strain jobs' were about 15 times more likely $(\mathrm{OR}=15.75$; IC $=1.74$ $142.55)$ to present a suspicion of an MPD than those classified in the quadrant 'low strain jobs'. Those in the quadrant 'high strain jobs' also were approximately 11 times more likely (OR=11.91; IC95\%=1.47-95.95) to present suspicion of an MPD than those in the 'low strain jobs' quadrant.

The co-variables 'schooling' and 'research' were revealed to be potential confounding factors (associated both to exposure and outcome) during the bivariate analysis. However, even though the covariable 'research' presented a statistically significant difference, it was not included in the logistic regression model due to the impossibility of comparing it among the groups (those not performing research activities did not present suspicion of an MPD). Even after adjusting for potentially confounding co-variable (schooling), the chance of the participants being classified as potentially having an MPD remained in both quadrants. Hence, a positive association was verified between 'high strain jobs' (OR=10.05; CI 95\%=1.23-82.44), 'active strain jobs' $(O R=14.23$; CI 95\%=1.55-130.73), and MPDs.

\section{Discussion}

Cronbach's alpha evaluates the internal consistency or homogeneity of questions intended to measure a 
given construct. The JSS's general Cronbach's alpha was 0.54 , which demonstrates satisfactory internal consistency ${ }^{(17)}$, even though the value is below that obtained for the quadrants in the validation of the scale for Portuguese(5). It is worth noting that the use of translated and cross-culturally adapted instruments may be a factor limiting understanding of questions on the part of the interviewees, as may be the case with the question "Do you have to do the same thing over and over again?" The participants may have not recognize some repetitive activities such as advising students. In this study, the nursing professors advised five or more students. Sequential advising is a repetitive activity, however, as it occurs with different students addressing diverse subjects, the repetitive nature of the task may go unnoticed. Factors of this nature may have interfered in the scale's alpha value.

When 'psychological demand' and 'decision latitude' were combined to compose the DC Model's quadrants, we observed that the highest frequency of nursing professors were classified in the quadrant 'high strain jobs' followed by 'passive strain jobs', 'low strain jobs' and 'active strain jobs'. Different data were found in the study conducted with teachers from the primary school. There, the highest percentage of teachers was allocated in the quadrants 'low strain jobs' and 'active strain jobs' $\left(1 / 3\right.$ each) ${ }^{(14)}$. In another study, the distribution of nursing workers in the four quadrants was the following: $20.4 \%$ 'low strain jobs'; $21.2 \%$ 'high strain jobs'; $28.5 \%$ 'active strain jobs' and $29.9 \%$ 'passive strain jobs'(7).

This difference in the classification of workers in the DC Model's quadrants may be explained by the work dynamics experienced by the studied professionals (nursing workers, secondary school teachers, and nursing professors). In relation to the work of nursing professors (at a college level), prolonged activities may be more frequent because in addition to preparing classes and tests, they advise undergraduate, undergraduate research and graduate students, conduct research projects, extension activities, and administer practical classes in the hospital environment and in primary health care units. It seems that the work of nursing professors combines the effects of their activity as nurses and as professors, resulting in greater psychological demands, which can affect their psychological health. Additionally, Brazilian federal universities are experiencing a restructuring process due to the downsizing of the support services staff and the implementation of new technologies. This change has imposed an increasing demand of a cognitive nature on professors as they become responsible for the decisionmaking that controls the work processes and also solving problems that result from them ${ }^{(18)}$, as well as experiencing external pressure accruing from different controlling and evaluating agencies.

Scores above seven were obtained by the nursing professors (20.1\%) on the SRQ-20. This result is above that found in studies addressing nursing workers(7) and professors from higher education ${ }^{(19)}$ intuitions and below the results of studies addressing primary school teachers ${ }^{(2,14)}$, physicians ${ }^{(20)}$, medical students ${ }^{(21)}$, South African students from the health field(22), and dentists.

The DC Model's(3) main hypothesis that high strain jobs predict health risks was confirmed in this study. Nursing professors classified in the quadrant 'high strain jobs' do have a greater chance of being classified as potentially having an MPD than those who are located in the 'low strain jobs' quadrant $(\mathrm{OR}=10.05$; CI 95\%=1.2382.44).

However, nursing professors determined to be in the quadrant 'active strain jobs' also presented a greater likelihood of presenting an MPD when compared to those in the 'low strain jobs' (OR=14.23; CI 95\%=1.55130.73). A study ${ }^{(19)}$ whose objective was to present the theoretical and methodological foundations of the DC Model and discuss its ability to identify different job situations in the Brazilian context reported that the model's two dimensions appear as independent attributes, though in the case of 'active strain jobs', high demands could block reinforcements coming from high decision latitude, which indicates that 'active strain jobs' may also be harmful to the psychological health of nursing professors.

Results similar to those found in this study were also identified in other studies, which verified that workers in 'high strain jobs' were more likely to be classified as potentially leading to an MPD than those in 'low strain jobs' even after adjusting for potential confounding variables $^{(7,13,19-20)}$.

It is worth noting that the context of teaching is more complex than the results found in this study reveal. Though it is apparent that an imbalance arising from job demands and decision latitude can cause mental suffering.

Among the limitations of this study we note the large magnitude of confidence intervals, possibly due to the population's size and the prevalence of the outcome (MPD), which may overestimate the odds ratio. Additionally, it is not possible to confirm the presence of causal relationships with certainty since cross-sectional 
studies simultaneously view the subject's exposure and their health condition(23); therefore, reverse causality cannot be disregarded. Also, even though the DC Model is intended for generalized use, it does not necessarily take into account the peculiarities of the nature of the work involving the relationship among people, since it was originally built to be applied to industry workers (24).

It is important to note that there are few published studies addressing higher education professors. This gap hindered comparison of results. Nevertheless, this deficiency was remedied through comparison of data found in this study with those originating in studies conducted with nurses from the hospital field and primary school teachers.

\section{Conclusion}

The conclusion is that nursing professors developing activities within 'high strain jobs' have a greater chance of developing an MPD when compared to those performing activities within 'low strain jobs'. It is also apparent that those classified in the quadrant 'active strain jobs' also present a greater likelihood of being affected by mental disease than those classified in 'low strain jobs'. Such a fact is in agreement with the model's assumptions, suggesting that a high psychological demand negatively affects nursing professors, even when these workers have a high level of control over their work.

Nursing professionals should intensify research and establish strategies to promote health within the work routine to contribute to the autonomy of workers as well as to identify new means to promote wellbeing in the workplace. Moreover, it is essential that nursing professors rethink their nursing education and seek to implement to curricula focusing on promoting the health of workers.

Finally, the complexity of the work conditions of nursing professors is a reason for further studies addressing other occupational disorders, as well as the use of other scales to evaluate psychosocial aspects.

\section{References}

1. Silva NEM, Figueirêdo DS, Freitas CES, Araújo TM, Paranhos IS. Trabalho docente e saúde em uma instituição de ensino superior da Bahia. In: VI Seminário da REDESRADO-Regulação Educacional e Trabalho Docente; 06-07 novembro 2006; Rio de Janeiro: UERJ; 2006. p. 1-13.

2. Reis EJFB, Carvalho FM, Araújo TM, Porto LA, Silvany Neto AM. Trabalho e distúrbios psíquicos em professores da rede municipal de Vitória da Conquista, Bahia, Brasil. Cad Saúde Pública 2005;21(5):1480-90.

3. Karasek RA, Theörell T. Healthy work-stress, productivity, and the reconstruction of working life. New York: Basic Books; 1990.

4. Silva JLL, Nóbrega ACR, Brito FGF, Gonçalves RG, Barbara Soares Avanci BS. Stress at work and the common mental disorders prevalence among nursing workers. Rev Enferm UFPE on Line. 2011; [acesso 13 jan 2010];5(1):1-9. Disponível em: http://www.doaj. org/doaj?func $=$ openurl\&genre $=$ journal\&issn $=19818963$ \&volume $=5 \&$ issue $=1 \&$ date $=2011$

5. Alves MGM, Chor D, Faerstein E, Lopes CS, Werneck GL. Versão resumida da "job stress scale" adaptação para o português. Rev Saúde Pública 2004;38(2): 164-71.

6. Magnago TSBS, Lisboa MTL, Griep RH, Kirchhof ALC, Guido LA. Aspectos psicossociais do trabalho e distúrbio musculoesquelético em trabalhadores de enfermagem. Rev. Latino-Am. Enfermagem. 2010;18(3):140-7.

7. Kirchhof ALC, Magnago TSBS, Camponogara S, Griep RH, Tavares JP, Prestes FC, et al. Condições de trabalho e características sócio-demográficas relacionadas à presença de distúrbios psíquicos menores em trabalhadores de enfermagem. Texto Contexto Enferm. 2009;18(2):215-23.

8. Macedo LET, Chor D, Andreozzi V, Faerstein E, Werneck GL,Lopes CS. Estresse no trabalho e interrupção de atividades habituais, por problemas de saúde, no Estudo Pró-Saúde. Cad Saúde Pública. 2007;23(10):2327-36.

9. Ballone JG, Pereira E Neto, Ortoloni IV. Da emoção à lesão. São Paulo: Manole; 2002.

10. Ministério da Saúde (BR). Doenças relacionadas ao trabalho: manual de procedimentos para os serviços de saúde 2001. Brasília: Ministério da Saúde; 2001.

11. Cerchiari EAN, Caetano D, Faccenda O. Prevalência de Transtornos Mentais Menores em Estudantes Universitários. Estud Psicol. 2005;10(3):413-20.

12. Maragno L,Goldbaum M, Gianini RJ, Novaes Hillegonda MD, César CLG, et al. Prevalência de transtornos mentais comuns em populações atendidas pelo Programa Saúde da 48.

13. Araújo TM, Aquino E, Menezes G, Santos CO, Aguiar L. Aspectos Psicossociais do trabalho e distúrbios psíquicos entre trabalhadores da enfermagem. Rev Saúde Pública. 2003;37(4):24-33.

14. Porto LA, Carvalho FM, Oliveira NF, Silvany AM Neto, Araújo TM, Reis EJFB, et al. Associação entre distúrbios psiquiátricos e aspectos psicossociais do trabalho de professores. Rev Saúde Pública. 2006;40(5):818-26. 
15. Pinel I, Kurcgant P. Reflexões sobre competência docente no ensino de enfermagem Rev Esc Enferm USP. 2007;41(4):711-6.

16. Mari JJ, Williams P. A validity study of a psychiatric screening questionnaire (SQR-20) in primary care in the city of São Paulo. Br J Psychol. 1986;148:23-6.

17. Bailar J, Mosteller F. Medical users of statistics. Boston: Nejm Books; 1992.

18. Abrahão JI. Reestruturação Produtiva e Variabilidade do Trabalho: uma Abordagem da Ergonomia. Psicol Teoria Pesq. 2000;1(16):46-54.

19. Araújo TM, Graça CC, Araújo E. Estresse ocupacional e saúde: contribuições do Modelo Demanda- Controle. Ciênc Saúde Coletiva. 2003;8(4):991-1003.

20. Nascimento SCL. Condições de trabalho e saúde dos médicos em Salvador, Brasil. Rev Assoc Med Bras. 2006;52(2):97-102.

21. Lima MCP, Domingues MS, Cerqueira ATAR. Prevalência e fatores de risco para transtornos mentais comuns entre estudantes de medicina. Rev Saúde Pública. 2006;40(6):1035-41.

22. Gelman T, Swartz L, Tredoux C, Strauss R. Minor Psychiatric Morbidity in Students Attending a South African University Health Service. J Clin Psychol Med Settings 2001;8(2):131-6.

23. Klein $\mathrm{CH}$, Bloch $\mathrm{KV}$. Estudos seccionais. In: Medronho R, Carvalho DM, Bloch KV, Luiz RR, Wernek GL. Epidemiologia. São Paulo: Atheneu; 2005.

24. Griep RH, Rotenberg L, Vasconcellos AGG, Landsbergis $\mathrm{P}$, Comaru CM, Alves MGM. The psychometric properties of demand-control and effort-reward imbalance scales among Brazilian nurses. Int Arch Occup Environ Health. 2009;82:1163-72. 